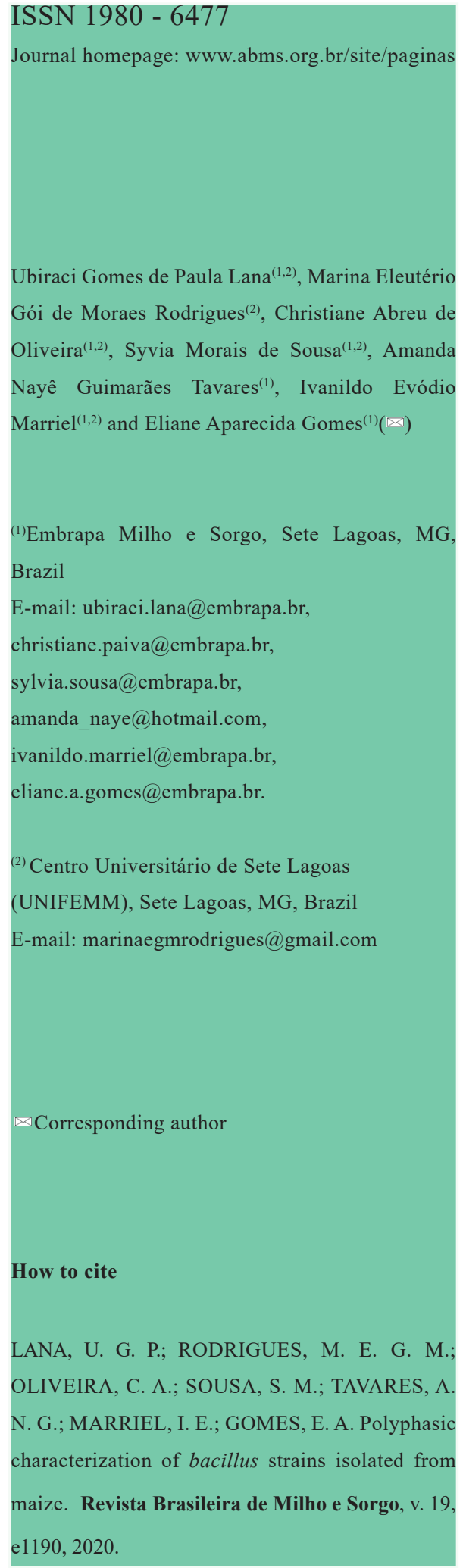

\section{POLYPHASIC CHARACTERIZATION OF Bacillus STRAINS ISOLATED FROM MAIZE}

\begin{abstract}
The use of bioinoculants with plant growth-promoting bacteria (PGPB) is a sustainable agricultural practice that has been expanding worldwide. Thus, it is fundamental to characterize these bacteria molecularly to provide better security and traceability for bioinoculants production. This work aimed to identify, characterize and develop specific molecular markers for Bacillus strains related to plant-growing promotion. Five strains were identified as B. pumillus (B32), B. thuringiensis (B116), B. megaterium (B119) and B. subtilis (B2082 and B2084), using $16 S$ rRNA gene sequencing, MALDI-TOF mass spectrometry and/or protein crystal detection. Repetitive element palindromic (Rep-PCR) and amplified ribosomal DNA restriction analysis (ARDRA) techniques allowed the discrimination of the strains, except B2082 and B2084 that presented identical genetic profiles, indicating that they are the same or genetically close isolates. Moreover, specific molecular markers were developed for B116 and B119 strains and may be used for microbial inoculants quality control, strains traceability and to detail PGPB colonization.
\end{abstract}

Keywords: Bacteria, molecular fingerprinting, plant growth-promoting, Zea mays L.

\section{CARACTERIZAÇÃO POLIFÁSICA DE CEPAS DE Bacillus ISOLADAS DE MILHO}

Resumo - O uso de bioinoculantes com bactérias promotoras de crescimento de plantas (BPCP) é uma prática agrícola sustentável que vem se expandindo em todo o mundo. Assim, é fundamental caracterizar essas bactérias molecularmente para proporcionar melhor segurança e rastreabilidade para a produção de bioinoculantes. Este trabalho teve como objetivo identificar, caracterizar e desenvolver marcadores moleculares específicos para cepas de Bacillus relacionadas à promoção de crescimento de plantas. Cinco cepas foram identificadas como B. pumillus (B32), B. thuringiensis (B116), B. megaterium (B119) e B. subtilis (B2082 e B2084) utilizando o sequenciamento do gene $16 \mathrm{~S} r R N A$, espectrometria de massas MALDI-TOF e/ou a detecção de cristais proteicos. As técnicas de análise de elementos repetitivos palindrômicos (Rep-PCR) e restrição do DNA ribossômico amplificado (ARDRA) permitiram a discriminação das cepas, exceto B2082 e B2084 que apresentaram perfis genéticos idênticos, indicando que são iguais ou isolados geneticamente próximos. Além disso, marcadores moleculares específicos foram desenvolvidos para as cepas B116 e B119 e podem ser utilizados para controle de qualidade de inoculantes microbianos, rastreabilidade das cepas e para detalhar a colonização por BPCP.

Palavras-chave: Bactéria, perfil molecular, promoção de crescimento de plantas, Zea mays L. 
Maize crop is one of the main commodities of Brazilian agribusiness, given its different forms of use, ranging from animal feed and human food to the high-tech industry. To obtain high yield in maize crop, it is necessary to apply several farm inputs to the soil. Synthetic fertilizers comprise most of maize production cost and can cause several adverse environmental impacts, such as the eutrophication of water sources, soil degradation, micronutrient deficiency, toxicity to different beneficial organisms and reduction of microbiota biodiversity (Li et al., 2017). In this context, soil management practices and efficient genotypes, combined with bioinoculants, can be an efficient and sustainable alternative to mitigate these problems (Pereira et al., 2020; Santos et al., 2019). The use of bioinoculants, including the ones containing plant growth-promoting bacteria (PGPB), is a sustainable agricultural practice that has been expanding worldwide and shows positive results for several crops, including maize (Anzuay et al., 2017; Santos et al., 2019; Pereira et al., 2020). Maize can associate with several species of PGPB, including Bacillus (Velloso et al., 2019; de Sousa et al., 2020; Paiva et al., 2020). Bacillus is a heterogeneous group of gram-positive bacteria widely distributed in the environment, which comprises 293 species/ subspecies (Patel \& Gupta, 2020). Some Bacillus species are capable to solubilize phosphate (Bahadir et al., 2018), produce indole-acetic acid (IAA) and other phytohormones (Mohite, 2013), siderophores (Bjelić et al., 2018), and control plant pathogens and pest insects (Shafi et al., 2017). Recently, the first commercial bioinoculant was released, named BiomaPhos ${ }^{\circledR}$, carrying a consortium of two P-solubilizing/ mineralizing Bacillus strains (B. subtilis and $B$. megaterium), which was developed by our group (Paiva et al., 2020). Bioinoculants containing Bacillus strains are stable in the environment because of their ability to form spores, allowing them to adapt to extreme abiotic conditions, such as temperatures, $\mathrm{pH}$ or exposure to pesticides (Bahadir et al., 2018). Despite isolating and characterizing strains regarding plant growingpromotion potential, it is necessary to have a fast and efficient technique to identify the bacterial strains in order to provide greater security and traceability for biological products (Van Elsas \& Boersma, 2011; Reddypriya et al., 2018).

The most commonly employed target for molecular identification of bacteria is the $16 \mathrm{~S}$ ribosomal RNA gene (16S rDNA) sequencing, followed by comparison with genomic databases (Banik et al., 2015; Fuks et al., 2018; Johnson et al., 2019). Mass spectrometry by matrix-assisted laser desorption/ionization with a time-of-flight analyzer (MALDI-TOF) is another technique that has been used to discriminate close related species, including members of the Bacillus genus (Hotta et al., 2011; Ha et al., 2019).

Amplified ribosomal DNA restriction analysis (ARDRA) (Cihan et al., 2012) and PCR-based techniques using repetitive element palindromic PCR (Rep-PCR) (Versalovic et al., 1991) have been used for identification and taxonomy of prokaryotic microorganisms, 
including Bacillus genus (Kumar et al., 2014). The DNA sequences are amplified from highly conserved regions that present multiple copies in the genome of bacteria and the polymorphic DNA fragments are compared among the samples. Several repetitive sequences, such as repetitive extragenetic palindromes (REP), enterobacterial repetitive intergenic consensus-PCR (ERICPCR) and repetitive DNA elements (BOX) were identified and used to study the genetic diversity of Bacillus in different environments, allowing phylogenetic studies and discrimination of genetically close species (Rai et al., 2015; Wang et al., 2020).

Thus, the objective of this work was to identify, characterize and develop specific molecular markers for genetic discrimination of Bacillus strains previously selected as P-efficient solubilizing and candidates to be part of maize bioinoculants.

\section{Material and Methods}

\section{Morphological characterization of bacterial isolates}

Bacillus strains B32, B116, B119, B2082 and B2084 were selected from the Collection of Multifunctional and Phytopathogenic Microorganisms of Embrapa Milho e Sorgo for their ability to solubilize inorganic phosphate in vitro (Oliveira et al., 2009; Gomes et al., 2014; Abreu et al., 2017), as well as their plant growthpromoting capacity (de Sousa et al., 2018; Ribeiro et al., 2018; de Sousa et al. 2020).
The Bacillus strains, stored in glycerol $15 \% \quad(\mathrm{v} / \mathrm{v})$ at $-80{ }^{\circ} \mathrm{C}$, were reactivated by streaking on potato dextrose agar - PDA medium (200 g.L. - $^{-1}$ potato, 20 g.L. $\mathrm{L}^{-1}$ dextrose and 15 g.L $\mathrm{L}^{-1}$ of agar, $\mathrm{pH}$ 7.0) and incubating at $28{ }^{\circ} \mathrm{C}$ for $72 \mathrm{~h}$. The colonies morphological characteristics and Gram coloration were evaluated in a microscopy (Axioplan, Carl Zeiss, Germany) with digital zoom (Paiva et al., 2013). B116 strain was also grown in solid Luria-Bertani (LB) medium and incubated at $29^{\circ} \mathrm{C}$ for 72 hours to confirm its identity. The cells were suspended with 10 $\mathrm{mL}$ autoclaved deionized water and used for determination of protein crystal inclusions by phase contrast microscopy.

\section{Extraction of genomic DNA}

A single colony from each strain was inoculated into conical tubes containing $3 \mathrm{~mL}$ of Tryptic Soy Broth - TSB medium (17 g. $\mathrm{L}^{-1}$ peptone casein, $3 \mathrm{~g} . \mathrm{L}^{-1}$ soy peptone, 5 g.L $\mathrm{L}^{-1}$ sodium chloride, 2.5 g. $\mathrm{L}^{-1}$ dipotassium hydrogen phosphate, and 2.5 g.L. $\mathrm{L}^{-1}$ glucose) and grown at $28{ }^{\circ} \mathrm{C}$ at $150 \mathrm{rpm}$ for $24 \mathrm{~h}$. Subsequently, the culture was centrifuged at $16,000 \mathrm{x}$ g for 5 min. The supernatant was discarded and the genomic DNA from bacterial cells was extracted with the Wizard Genomic DNA Purification Kit (Promega, USA), according to the manufacturer's recommendations. DNA quantification was performed on a ND-1000 UV/ VIS spectrophotometer (Nanodrop Technologies, USA) and the samples were diluted to $20 \mathrm{ng} . \mu \mathrm{L}^{-1}$. 
Amplification and sequencing of $16 S \mathrm{rRNA}$ gene

The 16S rRNA gene was amplified with $8 \mathrm{~F}$ and 1492R primers (Turner et al., 1999). The 1,500 bp fragment was amplified with 20 ng DNA, 1.5 U Taq DNA Polymerase (Kapa Biosystem, USA), 5\% (v/v) DMSO, $0.5 \mu \mathrm{M}$ of each primer, $125 \mu \mathrm{M}$ of dNTPs, $1 \mathrm{X}$ reaction buffer (Kapa Biosystem, USA), and $2.5 \mathrm{mM} \mathrm{MgCl}_{2}$ in a final volume of $20 \mu \mathrm{L}$. The amplifications were performed on a Veriti 96-Well Thermal Cycler (Applied Biosystems, USA) with initial denaturation at $95{ }^{\circ} \mathrm{C}$ for $2 \mathrm{~min}, 35$ cycles of $30 \mathrm{~s}$ of denaturation at $94{ }^{\circ} \mathrm{C} ; 30 \mathrm{~s}$ of annealing at $55^{\circ} \mathrm{C} ; 1 \mathrm{~min}$ and $30 \mathrm{~s}$ of extension at $72{ }^{\circ} \mathrm{C}$, followed by a final extension for $10 \mathrm{~min}$ at 72 ${ }^{\circ} \mathrm{C}$. PCR product was verified by electrophoresis on $1.0 \%(\mathrm{w} / \mathrm{v})$ agarose gel with GelRed (Biotium Inc., USA). The amplified fragments were used for DNA sequencing and restriction enzyme analysis.

The $16 S$ rRNA gene amplified products were purified with Exo-Sap enzyme (GE HealthCare, USA), following manufacturer's recommendations. The sequencing reactions were prepared with Big Dye V3.1 kit (Applied Biosystems, USA), as recommended by manufacturer. The primers $8 \mathrm{~F}, 1492 \mathrm{R}$ and the internal primers 515F (Turner et al., 1999) and 902R (Hodkinson \& Lutzoni, 2009) were used for DNA sequencing. The cycle conditions were 30 cycles of $96{ }^{\circ} \mathrm{C}$ for $20 \mathrm{~s}, 50{ }^{\circ} \mathrm{C}$ for $15 \mathrm{~s}$, $60{ }^{\circ} \mathrm{C}$ for $4 \mathrm{~min}$. Samples were sequenced on ABI PRISM 3500xL DNA (Applied Biosystem,
USA) and sequences processed on Sequencher 4.1 program (Gene Codes Corporation, USA). Nucleotide sequences were compared against the Genbank database using the BLASTN program (Altschul et al., 1997).

\section{Amplified ribosomal DNA restriction analysis (ARDRA)}

The 16S rRNA gene sequences from the five bacterial strains were analyzed in silico for restriction enzyme sites using NEBcutter V2.0 software (http://tools.neb.com/NEBcutter2/) and then the $16 S$ rRNA amplified products were digested with Taq I enzyme (Thermo Fisher, USA) at $65{ }^{\circ} \mathrm{C}$ for $2 \mathrm{~h}$ and verified by electrophoresis on $1.0 \%(\mathrm{w} / \mathrm{v})$ agarose gel stained with GelRed (Biotium Inc., USA).

\section{Rep PCR - amplification with ERIC and REP- PCR primers}

DNA amplification of the isolates was performed with primers ERIC1R (5'-ATGTAAGCTCCTGGGGATTCAC-3') and ERIC2 (5'-AAGTAAGTGACTGGGGT GAGG3');REP1R (5'-ATTAAAGTTTCACTTT AT3') and REP2 (5'-TTTAATC AGTGGGG-3') (Versalovic et al., 1991). The reaction was carried out in final volume of $20 \mu \mathrm{L}$ containing $20 \mathrm{ng}$ of DNA; $1 \mathrm{X}$ reaction buffer; $2.5 \mathrm{mM} \mathrm{MgCl}$; 250 $\mu \mathrm{M}$ of dNTP; $0.5 \mu \mathrm{M}$ of primer; $5 \%$ (v/v) DMSO and 1.5 U Platinum Taq DNA Polymerase (Invitrogen, USA). Amplification was performed on the Veriti 96-Well Thermal Cycler (Applied Biosystems, USA) with the following cycles: 95 
${ }^{\circ} \mathrm{C}$ for 3 min, followed by 40 cycles of $94{ }^{\circ} \mathrm{C}$ for 1 min, $45^{\circ} \mathrm{C}$ for $1 \mathrm{~min}, 72^{\circ} \mathrm{C}$ for $2 \mathrm{~min}$, and a final extension of $72^{\circ} \mathrm{C}$ for $10 \mathrm{~min}$. PCR products were analyzed by electrophoresis on $1.0 \%(\mathrm{w} / \mathrm{v})$ agarose gel stained with GelRed (Biotium Inc., USA).

\section{Development of specific primers based on genome analysis}

Specific primers were designed with the software Primer 3 Plus (https://primer3plus. com) based on B116 and B119 genomes previously available (JABXFG000000000.1 and JABXFF000000000.1, respectively). The specificity of the primers was checked using the BLAST N on GenBank (Altschul et al., 1997) and used for the amplification with 40 ng of DNA (from each Bacillus strain); 4\% DMSO (v/v); 0.5 $\mu \mathrm{M}$ of each primer; $250 \mu \mathrm{M}$ of dNTPs; $1 \mathrm{X}$ reaction buffer (Invitrogen, USA); $1.5 \mathrm{mM} \mathrm{MgCl}_{2}$ and $1.5 \mathrm{U}$ Platinum Taq DNA Polymerase (Invitrogen, USA) in a total volume of $20 \mu \mathrm{L}$. The cycle was $95^{\circ} \mathrm{C}$ for $3 \mathrm{~min}$, followed by 30 cycles at $95^{\circ} \mathrm{C}$ for $30 \mathrm{~s} ; 60.5$ ${ }^{\circ} \mathrm{C}$ for $30 \mathrm{~s} ; 1 \mathrm{~min}$ at $72{ }^{\circ} \mathrm{C}$, and a final extension at $72{ }^{\circ} \mathrm{C}$ for $5 \mathrm{~min}$. A serial dilution of genomic DNA from B116 and B119 strains (10 ng to 100 pg), mixed with $10 \mathrm{ng}$ of maize DNA extracted with the Wizard Genomic DNA Purification Kit (Promega, USA), was performed in duplicate to analyze primers specificity. The PCR fragments were confirmed by DNA sequencing as described above.

\section{Taxonomic analysis by ribosomal protein profile}

The protein profile analysis from the Bacillus strains was performed by MALDITOF mass spectrometry (Barbuddhe et al., 2008) at the facility on the National Reference

Laboratory for Aquatic Animal Diseases (UFMG, Brazil). Mass spectra were processed with the Bruker Daltonik MALDI Biotype software package (Bruker, Germany) and the results were obtained from the best identification match.

\section{Results}

\section{Bacillus colony morphological characterization}

The strains B32 and B116 showed predominantly circular beige colonies with convex elevation and smooth surface border. B119 strain presented circular colonies with gray coloration, convex elevation and a border with slightly rough surface. The colonies of B2082 and B2084 isolates were similar, with a circular shape of beige coloration and a convex elevation border with smooth surface. All strains are Gram positive and rod-shaped (Figure 1). 

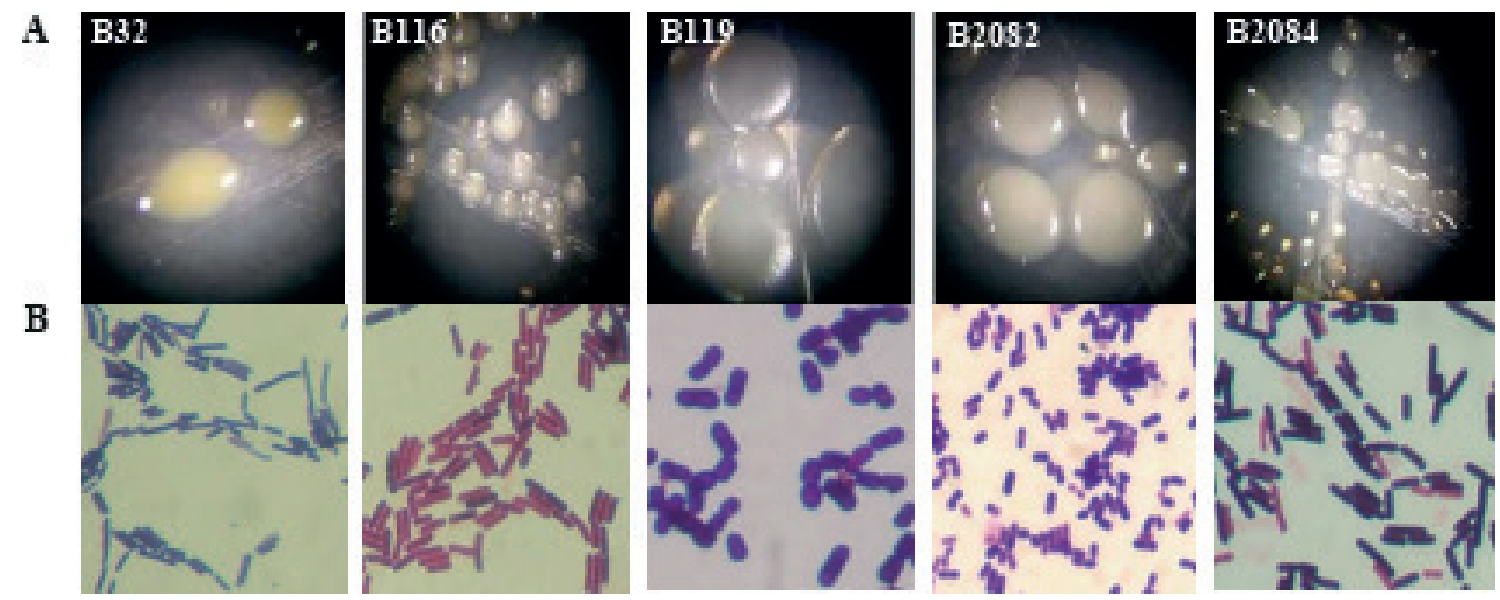

Figure 1. Colony morphology (A) and Gram staining (B) of Bacillus strains isolated from maize grown on Potato Dextrose Agar medium at $28^{\circ} \mathrm{C}$ for $72 \mathrm{~h}$.

Identification and bacterial fingerprint The 16S rRNA sequences of bacterial strains showed lower E-values and an identity greater than $99 \%$ comparing with known species (Table 1), which corroborated the protein analysis by MALDITOF, confirming that the isolates belong to the genus Bacillus, identified as B. pumilus, $B$. thuringiensis, $B$. megaterium and $B$. subtilis (Table 1).

An alternative for fast characterization and differentiation of Bacillus strains is ARDRA (amplified ribosomal DNA restriction analysis) and Rep-PCR (repetitive element palindromic PCR with ERIC and REP primers) analyses. During ARDRA, $16 \mathrm{~S} r \mathrm{DNA}$ sequences from the five strains were aligned and compared in silico to search for restriction sites. The restriction enzyme $T a q$ I discriminated most of the isolates, except B2082 and B2084, and it was used in the digestion of the amplification products of
16S rDNA gene, showing three to five well discriminated DNA fragments ranging from 100 to 1,000 bp for B32, B116 and B119 strains (Figure 2A). The amplification of the DNA with ERIC-PCR primers revealed between two and nine fragments with sizes ranging from 250 to 2,000 bp, whereas for REP primers, between two and six fragments with sizes ranging from 200 to $5,000 \mathrm{bp}$ (Figure 2B and 2C). These approaches allowed the genetic discrimination of the Bacillus strains, except B2082 and B2084 that showed identical profiles.

\section{Development of specific molecular markers}

Specific primers for detection of B116 (B. thuringiensis) and B119 (B. megaterium) strains were developed and their specificities were confirmed by amplification and sequencing of single PCR product of 533 and $550 \mathrm{bp}$, observed 
Table 1. Molecular identification of bacterial strains based on $16 S r R N A$ gene sequencing and protein profile using MALDI-TOF mass spectrometry

\begin{tabular}{|c|c|c|c|c|c|c|c|}
\hline \multicolumn{7}{|c|}{ Best alignment with GenBank using Blast N } & \multicolumn{2}{c|}{ MALDI-TOF } \\
\hline Strain & $\begin{array}{c}\text { 16S rDNA } \\
\text { (bp) }\end{array}$ & Species & E-value & $\begin{array}{c}\text { Similarity } \\
(\%)\end{array}$ & $\begin{array}{c}\text { Genbank } \\
\text { Access }\end{array}$ & Species & $\begin{array}{c}\text { Score with } \\
\text { Bruker } \\
\text { database* }\end{array}$ \\
\hline B32 & 1,512 & Bacillus pumilus & 0.0 & 99.8 & KR780583 & B. pumilus & 2.25 \\
B116 & 1,416 & B. thuringiensis & 0.0 & 99.9 & MG733925 & B. thuringiensis** & 1.96 \\
\hline B119 & 1,396 & B. megaterium & 0.0 & 99.9 & MK629317 & B. megaterium & 2.05 \\
B2082 & 1,490 & B. subtilis & 0.0 & 99.2 & NR_102783 & B. subtilis & 2.05 \\
\hline B2084 & 1,516 & B. subtilis & 0.0 & 99.5 & GQ421472 & B. subtilis & 2.27 \\
\hline
\end{tabular}

*Values between 2.3 and 3.0 are equivalent to highly probable species identification; scores between 2.0 and 2.29 provide secure genus identification and probable species identification; and between 1.7 and 1.9, probable genus identification.

** Bacillus thuringiensis confirmed by protein crystal inclusions (data not shown).

A

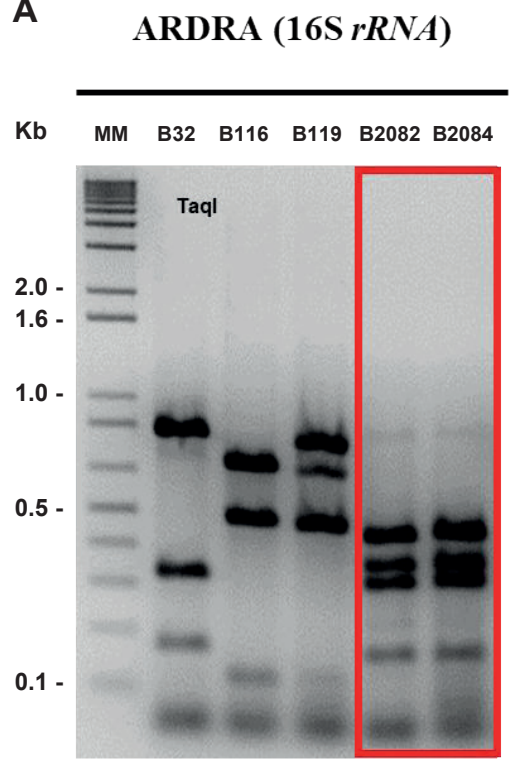

B

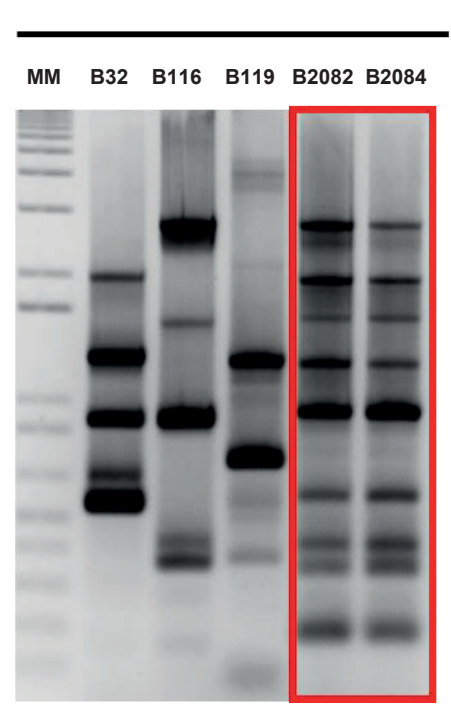

C
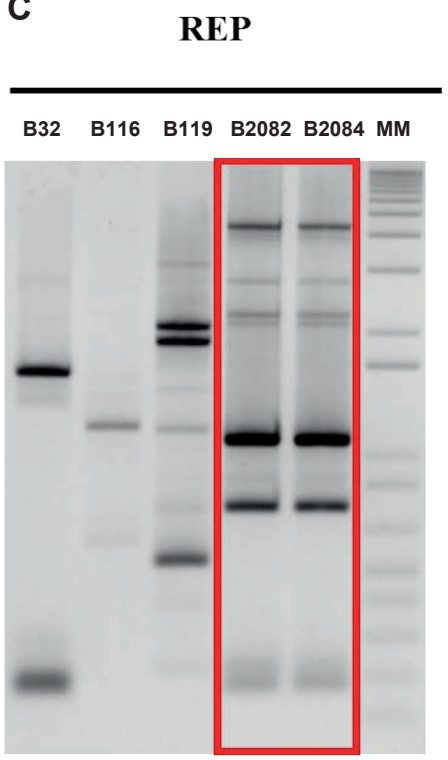

Figure 2. Molecular fingerprinting of the Bacillus strains B32, B116, B119, B2082 and B2084 obtained by A) ARDRA, B) ERIC and C) REP primers. MM = $1 \mathrm{~Kb}$ plus DNA ladder (Invitrogen, USA). The red rectangles highlight the identical profiles of B2082 and B2084 strains. 
only in B116 and B119 strains, respectively (Figure 3). The PCR assays with developed primers were sensitive enough to detect as little as $1 \mathrm{pg}$ of genomic DNA for B116 and $100 \mathrm{fg}$ for B119 strain (Figure 3).

A
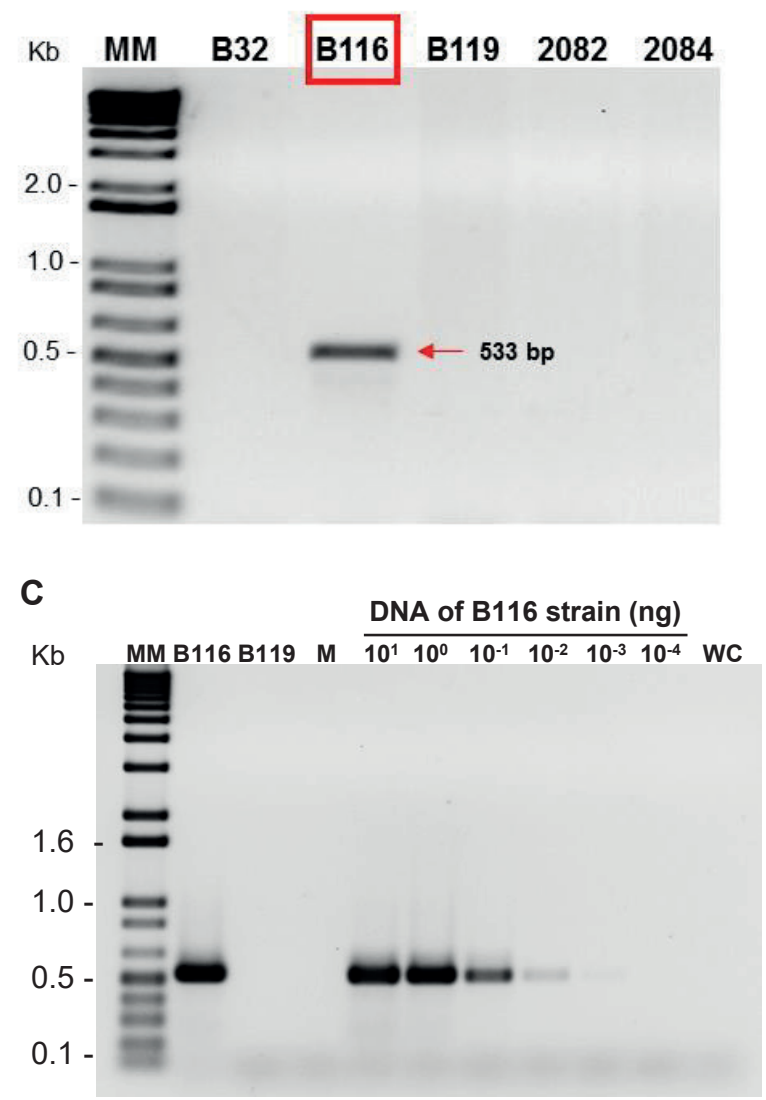

\section{Discussion}

Scientists from all over the world have focused their attention on sustainable agriculture by exploiting beneficial microbes in order to increase the contribution of bioinoculants to

B

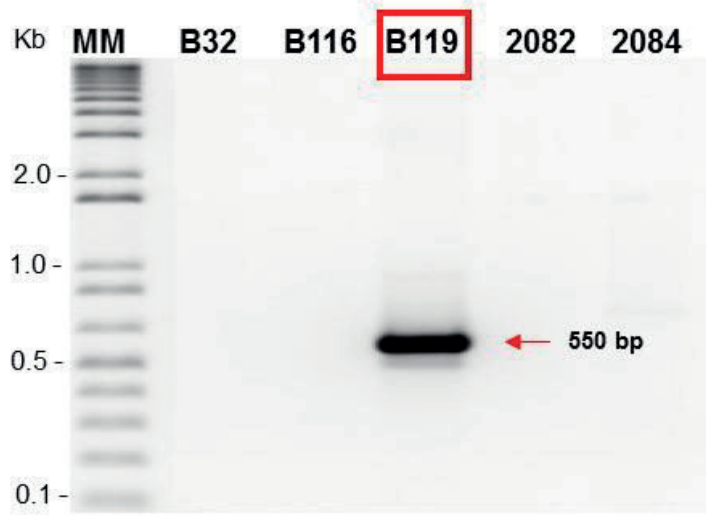

D

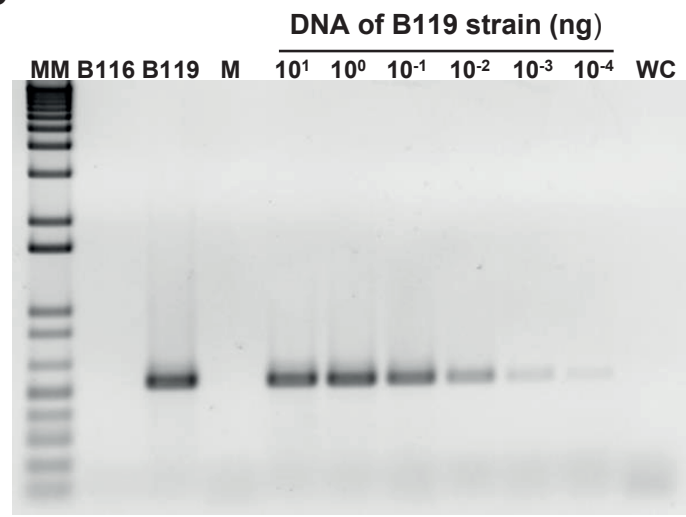

Figure 3. Amplification products with strain-specific primers. A) PCR product amplified with specific primers for B116 strain (Bacillus thuringiensis); B) PCR product with specific primers for B119 isolate (B. megaterium); C) Detection limit of primers specific for B116 strain and D) Detection limit of primers specific for B119 strain. M: maize DNA (10 ng). The values represent bacterial DNA quantity in ng used in PCR reaction containing $10 \mathrm{ng}$ of maize DNA. WC: water control. $\mathrm{MM}=1 \mathrm{~Kb}$ plus DNA ladder (Invitrogen, USA). The red arrows indicate specific PCR products. 
increase food, animal feed and biofuel production. Quality is one of the major concerns of bioinoculant technology which often leads to poor performance in the field and thereby loses the farmers' faith (Reddypriya et al., 2018). Strain authentication and detection of contaminants and pathogens for plant, animal, and human should be reinforced to ensure and control the quality of the bioinoculants produced (Soumare et al., 2020).

To address this issue, we explored different molecular techniques to characterize five Bacillus strains with plant growth-promotion capacity. Initially, we uncovered significant phenotypic differences among colonies on PDA medium. Bacillus species show a very wide range of colonial morphologies, both within and between species. Medium composition and other incubation conditions have a strong influence on colony morphology (Claus \& Berkeley, 1986). Despite this diversity, Bacillus colonies on routine media are not generally difficult to recognize (Logan \& De Vos, 2015). The colony morphology is a useful tool for a first screening, but normally it is not enough for the discrimination and/or identification at specie level. However, morphological description is useful, associated with molecular analyses and phylogenetic studies to perform a correct identification of the microorganisms (Silva et al., 2016a).

These isolates were confirmed as belonging to Bacillus genus by $16 S$ rRNA gene sequencing, the most commonly used method to identify bacteria and construct phylogenetic trees (Johnson et al., 2019). In some cases, due to the high percentage of sequence similarity, its resolution is limited, especially in species level. For example, eight species genetically close to $B$. subtilis could not be discriminated using $16 \mathrm{~S}$ rRNA gene sequencing as the gene sequence similarities between the strains were 98.1$99.8 \%$ (Wang et al., 2007). In our work, long length $16 S$ rRNA gene sequencing was used, which provided higher species-level resolution and accuracy and, when compared against sequences deposited in GenBank database, allowed Bacillus species identification. Our data were also confirmed by the MALDI-TOF approach that analyzes the profile of proteins, producing a spectrum characteristically derived mainly from ribosomal proteins of bacterial cells. Identification of Bacillus species through MALDI-TOF has been conducted for several years and is often applied to important clinical pathogens like B. anthracis and B. cereus (Jeong et al., 2013; Weller et al., 2015). Fernandez et al. (2013) compared the efficacy of proteomic approaches and nucleotide sequencing in the identification of Bacillus species. Their analysis concluded that MALDI-TOF was a good complementary approach to $16 S$ rRNA sequencing and even more accurate in the classification of Bacillus species, especially for differentiating $B$. subtilis and $B$. cereus from B. amyloliquefaciens and B. thuringiensis, respectively.

Bacteria of the genus Bacillus are grampositive, rod-shaped, and either aerobic or facultative anaerobes. They are characterized 
by their multilayered cell walls and their ability to form endospores resistant to various abiotic factors, such as heat, cold, extreme $\mathrm{pH}$ conditions, pesticides and fertilizers (Toyota, 2015). These features allow for the occupation of several agroecosystems and are favorable in the development of bioinoculants (Bahadir et al., 2018). In the present study, the isolate $B 32$ was identified as $B$. pumilus, a species that has been reported as aerobic, as well as having antifungal activity (Kaushal et al., 2017; Cruz et al., 2018). On the other hand, the isolate B116 was identified as $B$. thuringiensis, a bacterium that normally produces insecticidal crystal proteins against several insects, nematodes, protozoa and mites, being the species most widely used as biopesticide (Chattopadhyay et al., 2004; Sanahuja et al., 2011). In addition, under microscopy, it was possible to visualize the formation of protein crystal inclusions in the B116 strain (data not shown), which are the main taxonomic characteristic used in the differentiation of B. thuringiensis from other Bacillus species (Cherif et al., 2007). The species B. megaterium (B119) and B. subtilis (B2082 and B2084) have been reported to be efficient in phytopathogen biocontrol (Egamberdieva et al., 2017; DeFilippi et al., 2018) and in the amelioration of water stress tolerance in maize (Lima et al., 2019). Moreover, strains of the Bacillus genus isolated from both rhizospheric and endophytic sources have been reported to be efficient in growth-promoting of several plant species, including maize, whose main mechanism is normally associated with phosphate solubilization, indole acetic acid production and/or nitrogen fixation (Kumar et al., 2014; Silva et al., 2016b; Bodhankar et al., 2017; Khati et al., 2018; de Sousa et al., 2020).

The results based on ARDRA, ERIC and REP-PCR identified DNA polymorphisms and allowed for the strain differentiation, indicating that these approaches have a high discriminatory power. Only strains B2082 and B2084 (B. subtilis) presented the same profile, indicating that they probably refer to either the same or genetically close isolates. ARDRA and Rep-PCR are capable of revealing polymorphism in the DNA fragments, making them useful for a quick and detailed analysis of the genetic diversity (Versalovic et al., 1991). These methods have been used for the differentiation of bacterial species, including the identification of isolates with plant growing-promotion characteristics (Kumar et al., 2014; El-Sayed et al., 2014), or even in the characterization of strains within Bacillus species. For example, Sato et al. (2017) discriminated strains of $B$. coagulans using a combination of the MALDI-TOF and rep-PCR analysis. The use of different fingerprinting techniques, such as rep-PCR (REP, ERIC and BOX-PCR) is an interesting strategy to discriminated Bacillus from environmental samples (Kumar et al., 2014). The main advantage of these DNA fingerprinting approaches, in contrast to $16 \mathrm{~S}$ rDNA region sequencing, is their wide coverage of genetic diversity as they amplify regions distributed throughout the bacterial genome.

PCR assays with specific primers for 
the B116 and B119 strains demonstrated high sensibility without interference from maize DNA. Specific primers are useful in the detection and quantification of microorganisms. Oliwa-Stasiak et al. (2010) developed a PCR assay for the identification of $B$. cereus group species, based on a unique conserved sequence of the $\operatorname{mot} B$ gene (encoding flagellar motor protein), with detection limit equal to $1 \mathrm{pg}$. A DNA PCR assay, based on the glucanase gene, was developed for discrimination of $B$. subtilis, with a detection limit as little as $500 \mathrm{fg}$ of DNA (Ashe et al., 2014). The primers developed in the present study will be useful for the rapid identification of B116 and B119 strains.

Integrative approaches among $16 \mathrm{~S} r D N A$ sequencing, mass spectrometry, rep-PCR and protein crystal inclusions presence allowed the identification and discrimination of Bacillus species. The information generated can be useful for bacterial traceability, quality control of bioinoculants production, protecting commercial isolates against misuse by third parties, aside from contributing to the understanding of the mechanisms associated with bacterial colonization and plant growth-promotion. In addition, knowledge of the genetic profile of the Bacillus strains may contribute to the generation of a genetic profile database that will help in the genetic certification of the strains through governmental regulatory policies.

\section{Acknowledgments}

This work was supported by Empresa Brasileira de Pesquisa Agropecuária - Embrapa/ Simbiose (Grant № 01.13.05.001.02-0), Conselho Nacional de Desenvolvimento Científico e Tecnológico - CNPq/INCT- Plant-Growth Promoting Microorganisms for Agricultural Sustainability and Environmental Responsibility (Grant № 465133/2014-2, Fundação AraucáriaSTI, Capes) and Fundação de Amparo à Pesquisa do Estado de Minas Gerais - Fapemig (Grant № RED-00005-14).

\section{Conflict of Interest}

The authors declare that they have no conflict of interest.

\section{References}

ABREU, C. S. de; FIGUEIREDO, J. E. F.; OLIVEIRA, C. A.; SANTOS, V. L. dos; GOMES, E. A.; RIBEIRO, V. P.; BARROS, B. de A.; LANA, U. G. de P.; MARRIEL, I. E. Maize endophytic bacteria as mineral phosphate solubilizers. Genetics and Molecular Research, v. 16, n. 1, p. 1-13, 2017. DOI: 10.4238/ gmr16019294.

ALTSCHUL, S. F.; GISH, W.; MILLER, W.; MYERS, E. W.; LIPMAN, D. J. Basic local alignment search tool. Journal of Molecular Biology, v. 215, n. 3, p. 403-410, 1997. DOI: 
10.1016/S0022-2836(05)80360-2.

ANZUAY,M. S.; CIANCIO, M.G.R.; LUDUEÑA, L. M.; ANGELINI, J. G.; BARROS, G.; PASTOR, N.; TAURIAN, T. Growth promotion of peanut (Arachis hypogaea L.) and maize (Zea mays L.) plants by single and mixed cultures of efficient phosphate solubilizing bacteria that are tolerant to abiotic stress and pesticides. Microbiological Research, v. 199, p. 98-109, 2017. DOI: 10.1016/j. micres.2017.03.006.

ASHE, S.; MAJI, U. J.; SEN, R.; MOHANTY, S.; MAITI, N. K. Specific oligonucleotide primers for detection of endoglucanase positive Bacillus subtilis by PCR. 3 Biotech, v. 4, n. 5, p. 461-465, 2014. DOI: 10.1007/s13205-013-0177-6.

BAHADIR, P. S.; LIAQAT, F.; ELTEM, R. Plant growth promoting properties of phosphate solubilizing Bacillus species isolated from the Aegean Region of Turkey. Turkish Journal of Botany, v. 42, p. 183-196, 2018. DOI: 10.3906/ bot-1706-51.

BANIK, A.; MUKHOPADHAYA, S. K.; DANGAR, T. K. Characterization of $\mathrm{N}_{2}$-fixing plant growth promoting endophytic and epiphytic bacterial community of Indian cultivated and wild rice (Oryza spp.) genotypes. Planta, v. 243, n. 3, p. 799-812, 2015. DOI: 10.1007/s00425-015$2444-8$.
BJELIĆ, D.; MARINKOVIĆ, J.; TINTOR, B.; MRKOVAČKI, N. Antifungal and plant growth promoting activities of indigenous rhizobacteria isolated from maize (Zea mays L.) rhizosphere. Communications in Soil Science Plant Analysis, v. 49, n. 1, p. 88-98, 2018. DOI: 10.1 080/00103624.2017.1421650.

BARBUDDHE, S. B.; MAIER, T.; SCHWARZ, G.; KOSTRZEWA, M.; HOF. H.; DOMANN, E.; CHAKRABORTY, T.; HAIN, T. Rapid identification and typing of Listeria species by matrix-assisted laser desorption ionizationtime of flight mass spectrometry. Applied and Environmental Microbiology, v. 74, n. 17, p. 5402-5407, 2008. DOI: 10.1128/AEM.0268907.

BODHANKAR, S.; GROVER, M.; HEMANTH, S.; REDDY, G.; RASUL, S.; YADAV, S. K.; DESAI, S.; MALLAPPA, M.; MANDAPAKA, M.; SRINIVASARAO, C. Maize seed endophytic bacteria: dominance of antagonistic, lytic enzyme-producing Bacillus spp. 3Biotech, v. 7, n. 4, article 232, 2017. DOI: 10.1007/s13205-017-0860-0.

CHATTOPADHYAY,A.; BHATNAGAR, N. B.; BHATNAGAR, R. Bacterial insecticidal toxins. Critical Reviews in Microbiology, v. 30, p. 3354, 2004. DOI: 10.1080/10408410490270712.

CHERIF, A.; ETTOUMI, B.; RADDADI, N.; DAFFONCHIO, D.; BOUDABOUS, A. 
Genomic diversity and relationship of Bacillus thuringiensis and Bacillus cereus by multiREP-PCR fingerprinting. Canadian Journal of Microbiology, v. 53, n. 3, p. 343-350, 2007. DOI: 10.1139/W06-129.

CIHAN, A. C.; TEKIN, N.; OZCAN, B.; COKMUS, $\mathrm{C}$. The genetic diversity of genus Bacillus and the related genera revealed by $16 \mathrm{~s}$ rRNA gene sequences and ARDRA analyses isolated from geothermal regions of turkey. Brazilian Journal of Microbiology, v. 43, n. 1 , p. $309-324$, 2012. DOI: $10.1590 / \mathrm{S} 1517-$ 83822012000100037.

CLAUS, D.; BERKELEY, R. C. W. The genus Bacillus. In: BUCHANAN, R. E.; GIBBONS, N. E. (Ed.). Bergey's manual of determinative bacteriology. 2. ed. Baltimore: Williams \& Wikkins, 1986. p. 1105-1139.

CRUZ, M.; ACOSTA-SUÁREZ, M.; MENA, E.; ROQUE, B.; PICHARDO, T.; ALVARADOCAPÓ, Y. Effect of Bacillus pumilus CCIBP-C5 on Musa- Pseudocercospora fijiensis interaction. 3Biotech, v. 8, n. 2, article 122, 2018. DOI: 10.1007/s13205-018-1152-z.

DEFILIPPI, S.; GROULX, E.; MEGALLA, M.; MOHAMED, R.; AVIS, T. J. Fungal competitors affect production of antimicrobial lipopeptides in Bacillus subtilis Strain B9-5. Journal of Chemical Ecology, v. 44, n. 4, p. 374-383, 2018. DOI: 10.1007/s10886-018-0938-0.
EGAMBERDIEVA, D.; WIRTH, S. J.; SHURIGIN, V. V.; HASHEM, A.; ABD ALLAH, E. F. Endophytic bacteria improve plant growth, symbiotic performance of chickpea (Cicer arietinum L.) and induce suppression of root rot caused by Fusarium solani under salt stress.

Frontiers in Microbiology, v. 8, article 1887, 2017. DOI: 10.3389/fmicb.2017.01887.

EL-SAYED, W. S.; AKHKHA, A.; ELNAGGAR, M. Y.; ELBADRY, M. In vitro antagonistic activity, plant growth promoting traits and phylogenetic affiliation of rhizobacteria associated with wild plants grown in arid soil. Frontiers in Microbiology, v. 5, article 651, 2014. DOI: 10.3389/fmicb.2014.00651.

FERNANDEZ-NO, I. C.; BÖHME, K.; CAAMAÑO-ANTELO, S.; BARROSVELÁSQUEZ, J.; CALO-MATA, P. Characterisation and profiling of Bacillus subtilis, Bacillus cereus and Bacillus licheniformis by MALDI-TOF mass fingerprinting. Food Microbiology, v. 33, n. 2, p. 239-245, 2013. DOI: $10.1016 / \mathrm{j} . \mathrm{fm} .2012 .09 .022$.

FUKS, G.; ELGART, M.; AMIR, A.; ZEISEL, A.; TURNBAUGH, P. J.; SOEN, Y.; SHENTAL, N. Combining $16 S$ rRNA gene variable regions enables high-resolution microbial community profiling. Microbiome, v. 6 , n. 1, article 17, 2018. DOI: 10.1186/s40168-017-0396-X. 
GOMES, E. A.; SILVA, U. de C.; MARRIEL, I. E.; PAIVA, C. A. O.; LANA, U. G. de P. Rock phosphate solubilizing microorganisms isolated from maize rhizosphere soil. Revista Brasileira de Milho e Sorgo, v. 13, n. 1, p. 69-81, 2014. DOI: 10.18512/1980-6477/rbms.v13n1p69-81.

HA, M.; JO, H. J.; CHOI, E. K.; KIM, Y.; KIM, J.; CHO, H. J. Reliable identification of Bacillus cereus group species using low mass biomarkers by MALDI-TOF MS. Journal of Microbiology and Biotechnology, v. 29, n. 6, p. 887-896, 2019. DOI: 10.4014/jmb.1903.03033.

HODKINSON, B. P.; LUTZONI, F. A. Microbiotic survey of lichen-associated bacteria reveals a new lineage from the Rhizobiales. Symbiosis, v. 49, p. 163-180, 2009. DOI: 10.1007/s13199-009-0049-3.

HOTTA, Y.; SATO, J.; SATO, H.; HOSODA, A.; TAMURA, H. Classification of the genus Bacillus based on MALDI-TOF MS analysis of ribosomal proteins coded in $S 10$ and spc operons.

Journal of Agricultural and Food Chemistry, v. 59, n. 10, p. 5222-5230, 2011. DOI: 10.1021/ jf2004095.

JEONG, Y. S.; LEE, J.; KIM, S. J. Discrimination of Bacillus anthracis spores by direct in-situ analysis of matrix-assisted laser desorption/ ionization time-of-flight mass spectrometry. Bulletin of the Korean Chemical Society, v. 34, n. 9, p. 2635-2639, 2013.
DOI: 10.5012/bkcs.2013.34.9.2635.

JOHNSON, J. S.; SPAKOWICZ, D. J.; HONG, B.; PERTESEN, L. M.; DEMKOWICZ, P.; CHEN, L.; LEOPOLD, S. R.; HANSON, B. M.; OGRESTA, H. O.; GERSTEIN, M.; SODERGREN, E.; WEINSTOCK, G. M. Evaluation of $16 \mathrm{~S}$ rRNA gene sequencing for species and strain-level microbiome analysis. Nature Communications, v. 10, article 5029, 2019. DOI: 10.1038/s41467-019-13036-1.

KHATI, P.; PARUL; BHATT, P.; NISHA, KUMAR, R.; SHARMA, A. Effect of nanozeolite and plant growth promoting rhizobacteria on maize. 3 Biotech, v. 8, n. 3, article 141, 2018. DOI: $10.1007 / \mathrm{s} 13205-018-1142-1$.

KAUSHAL, M.; KUMAR, A.; KAUSHAL, R. Bacillus pumilus strain YSPMK11 as plant growth promoter and bicontrol agent against Sclerotinia sclerotiorum. 3 Biotech, v. 7, n. 2, article 90, 2017. DOI: 10.1007/s13205-0170732-7.

KUMAR, A.; KUMAR, A.; PRATUSH, A. Molecular diversity and functional variability of environmental isolates of Bacillus species. SpringerPlus, v. 3, article 312, 2014. DOI: 10.1186/2193-1801-3-312.

LI, H., MOLLIER, A., ZIADI, N., SHI, Y., PARENT, L. -EÉ, AND MOREL, C. The longterm effects of tillage practice and phosphorus 
fertilization on the distribution and morphology of corn root. 2017. Plant and Soil, v. 412, p.97114, 2017. DOI: 10.1007/s11104-016-2925-y.

LiMA, B. C., MORO, A. L., SANTOS, A. C. P., BONIFACIO, A., ARAUJO, A. S. F., AND DE ARAUJO, F. F. Bacillus subtilis ameliorates water stress tolerance in maize and common bean. Journal of Plant Interaction, v. 14, p. 432-439, 2019. DOI: 10.1080/17429145.2019.1645896.

LOGAN, N. A.; DE VOS, P. Bacillus. In: BERGEY'S manual of systematics of archaea and bacteria. New York: John Wiley \& Sons, 2015. p. 1-164.

MOHITE, B. Isolation and characterization of indole acetic acid (IAA) producing bacteria from rhizospheric soil and its effect on plant growth. Journal of Soil Science Plant Nutrition, v. 13, n. 3, p. 638-649, 2013. DOI: 10.4067/S071895162013005000051.

OLIWA-STASIAK, K.; MOLNAR， C. I.; ARSHAK, K.; BARTOSZCZE, M.; ADLEY, C. C. Development of a PCR assay for identification of the Bacillus cereus group species. Journal of Applied Microbiology, v. 108, n. 1, p. 266-273, 2010. DOI: 10.1111/j.1365-2672.2009.04419.x.

OLIVEIRA, C. A.; AlVES, V. M. C.; MARRIEL, I. E.; GOMES, E. A.; SCOTTI, M. R.; CARNEIRO, N. P.; GUIMARÃES, C. T.; SCHAFFERT, R. E.; SÁ, N. M. H. Phosphate solubilizing microorganisms isolated from rhizosphere of maize cultivated in an oxisol of the Brazilian Cerrado Biome. Soil Biology and Biochemistry, v. 41, p. 1782-1787, 2009. DOI: 10.1016/j.soilbio.2008.01.012.

PAIVA, C.A. O.; OLIVEIRA, M. C.; MARRIEL, I. E.; SOUZA, F. A. de; VALICENTE, F. H.; COTA, L. V. Manual de Gestão da Coleção de Microrganismos Multifuncionais e Fitopatogênicos da Embrapa Milho e Sorgo (CMMF). Sete Lagoas: Embrapa Milho e Sorgo, 2013. 47 p. (Embrapa Milho e Sorgo. Documentos, 153).

PAIVA, C. A. O.; MARRIEL, I. E.; GOMES, E. A.; COTA, L. V.; SANTOS, F. C. dos; SOUSA, S. M. de; LANA, U. G. de P.; OLIVEIRA, M. C.; MATTOS, B. B.; ALVES, V. M. C.; RIBEIRO, V. P.; VASCO JUNIOR, R. Recomendação agronômica de cepas de Bacillus subtilis (CNPMS B2084) e Bacillus megaterium (CNPMS B119) na cultura do milho. Sete Lagoas: Embrapa Milho e Sorgo, 2020. 18 p. (Embrapa Milho e Sorgo. Circular Técnica, 260).

PATEL, S.; GUPTA, R. S. A phylogenomic and comparative genomic framework for resolving the polyphyly of the genus Bacillus: proposal for six new genera of Bacillus species, Peribacillus gen. nov., Cytobacillus gen. nov., Mesobacillus gen. nov., Neobacillus gen. nov., Metabacillus gen. nov. and Alkalihalobacillus gen. nov. International Journal of Systematic 
Evolutionary Microbiology, v. 70, n. 1, p. 406438, 2020. DOI: 10.1099/ijsem.0.003775.

PEREIRA, N.C.M., GALINDO, F.S., GAZOLA, R.P.D., DUPAS, E., ROSA, P.A.L., MORTINHO, E.S. TEIXEIRA FILHO, M.C.M. Yield and phosphorus use efficiency response to phosphorus rates associated with plant growth promoting bacteria. Frontiers in Environmental Science, v. 8, article 40, 2020. DOI: 10.3389/ fenvs.2020.00040.

RAI, P.; SHARMA, A.; SAXENA, P.; SONI, A. P.; CHAKDAR, H.; KASHYAP, P. L.; SRIVASTAVA, A. K.; SHARMA, A. K. Comparison of molecular and phenetic typing methods to assess diversity of selected members of the genus Bacillus. Microbiology, v. 84, p. 236246, 2015. DOI: 10.1134/S0026261715020113.

REDDYPRIYA, P.; SOUMARE, A.; BALACHANDAR, D. Multiplex and quantitative PCR targeting SCAR markers for strain-level detection and quantification of biofertilizers. Journal of Basic Microbiology, v. 59, p. 111-119, 2018. DOI: 10.1002/jobm.201800318.

RIBEIRO, V.P., MARRIEL, I.E., DE SOUSA, S.M., LANA, U.G.P., MATTOS, B.B., OLIVEIRA, C.A., GOMES, E.A. Endophytic Bacillus strains enhance pearl millet growth and nutrient uptake under low-P. Brazilian Journal of Microbiology, v.49S, p. 40-46, 2018. DOI: 10.1016/j.bjm.2018.06.005.
SANAHUJA, G.; BANAKAR, R.; TWYMAN, R. M.; CAPELL, T.; CHRISTOU, P. Bacillus thuringiensis: a century of research, development and commercial applications.

Plant Biotechnology Journal, v. 9, n. 3, p. 283-300, 2011. DOI: 10.1111/j.1467-7652.2011.00595.x.

SANTOS, M. S.; NOGUEIRA, M. A.; HUNGRIA, M. Microbial inoculants: reviewing the past, discussing the present and previewing an outstanding future for the use of beneficial bacteria in agriculture. AMB Exprress, v. 9, n. 1, article 205, 2019. DOI: 10.1186/s13568-0190932-0.

SATO, J.; NAKAYAMA, M.; TOMITA, A.; SONODA, T.; HASUMI, M.; MIYAMOTO, T. Evaluation of repetitive-PCR and matrix-assisted laser desorption ionization-time of flight mass spectrometry (MALDI-TOF MS) for rapid strain typing of Bacillus coagulans. PLoS ONE, v. 12, n. 10, e0186327, 2017. DOI: 10.1371/journal. pone. 0186327.

SHAFI, J.; TIAN, H.; JI, M. Bacillus species as versatile weapons for plant pathogens: a review. Biotechnology \& Biotechnological Equipment, v. 31, n. 3, p. 446-459, 2017. DOI: 10.1080/13102818.2017.1286950.

SILVA, T. L.; SCHERER, A. J.; NAVROSKI, D.; KOCK, K.; BARREIROS, M. A. B.; GRANGE, L. Diversidade morfológica de Bacillus spp. obtidas de solos do oeste do Paraná sob diferentes 
sistemas de cultivo e natural. Revista Varia Scientia Agrárias, v. 5, n. 2, p. 109-123, $2016 \mathrm{a}$. SILVA, U. de C.; OLIVEIRA, C. A. de; LANA, U. G. de P.; GOMES, E. A.; SANTOS, V. L. dos. Growth promotion features of the maize microbiome: from an agriculture perspective. In: CHOUDHARY, D. K.; VARMA, A.; TUTEJA, N. (Ed.). Plant-microbe interaction: an approach to sustainable agriculture. Singapore: Springer, 2016b. cap. 16, p. 345-374.

SOUMARE, A.; BOUBEKRI, K.; LYAMLOULI, K.; HAFIDI, M.; OUHDOUCH, Y.; KOUISNI, L. From isolation of phosphate solubilizing microbes to their formulation and use as biofertilizers: status and needs. Frontiers in Bioengineering and Biotechnology, v. 7, article 425, 2020. DOI : 10.3389/fbioe.2019.00425.

SOUSA, S. M. de; OLIVEIRA, C. A.; ANDRADE, D. L.; CARVALHO, C. G.; RIBEIRO, V. P.; PASTINA, M. M.; MARRIEL, I. E.; LANA, U. G. P.; GOMES, E. A. Tropical Bacillus strains inoculation enhances maize root surface area, dry weight, nutrient uptake and grain yield. Journal of Plant Growth Regulation, 2020. DOI: 10.1007/s00344-020-10146-9.

SOUSA, S. M. de; PAIVA, C. A. O.; ANDRADE, D. L.; CARVALHO, C. G. de; RIBEIRO, V. P.; PASTINA, M. M.; MARRIEL, I. E.; LANA, U. G. de P.; GOMES, E. A. Cepas de Bacillus e Azospirillum aumentam o crescimento e a absorção de nutrientes em milho em condições hidropônicas. Sete Lagoas: Embrapa Milho e Sorgo, 2018. 31 p. (Embrapa Milho e Sorgo. Boletim de Pesquisa e Desenvolvimento, 184).

TOYOTA, K. Bacillus-related spore formers: attractive agents for plant growth promotion. Microbes and Environments, v. 30, n. 3, p. 205-207, 2015. DOI: 10.1264/jsme2.ME3003rh.

TURNER, S.; PRYER, K. M.; MIAO, V. P.; PALMER, J. D. Investigating deep phylogenetic relationships among cyanobacteria and plastids by small subunit rRNA sequence analysis. Journal of Eukaryotic Microbiology, v. 46, n. 4 , p. $327-338$, 1999. DOI: $10.1111 / \mathrm{j} .1550-$ 7408.1999.tb04612.x.

VAN ELSAS, J. D.; BOERSMA, F. G. H. A review of molecular methods to study the microbiota of soil and the mycosphere. European Journal of Soil Biology, v. 47, n. 2, p. 77-87, 2011. DOI: 10.1016/j.ejsobi.2010.11.010.

VElloso, C. C. V.; CARVAlHO, C. G.; PAIVA, C. A. O.; LANA, U. G. de P.; GOMES, E. A.; PASTINA, M. M.; GUIMARÃES, L. J. M.; SOUSA, S. M. de. Resposta diferencial de genótipos de milho à inoculação com bactérias promotoras do crescimento de plantas. Sete Lagoas: Embrapa Milho e Sorgo, 2019. 27 p. (Embrapa Milho e Sorgo. Boletim de Pesquisa e Desenvolvimento, 203). 
VERSALOVIC, J.; KOEUTH, T.; LUPSKI, J. WANG, Z.; YU, Z.-X.; SOLANKI, M. K.; R. Distribution of repetitive DNA sequences in YANG, L.-T.; XING, Y.-X.; DONG, D.-F.; LI, eubacteria and application to fingerprinting of bacterial genomes. Nucleic Acids Research, v. 19, n. 24, p. 6823-6831, 1991. DOI: 10.1093/ nar/19.24.6823.

Y.-R. Diversity of sugarcane root-associated endophytic Bacillus and their activities in enhancing plant growth. Journal of Applied Microbiology, v. 128, p. 814-827, 2020. DOI: 10.1111/jam.14512.

WANG, L. T.; LEE, F. L.; TAI, C. J.; KASAI, H. Comparison of gyrB gene sequences, $16 S r R N A$ gene sequences and DNA-DNA hybridization in the Bacillus subtilis group. International Journal of Systematic and Evolutionary Microbiology, v. 57, p. 1846-1850, 2007. DOI: 10.1099/ijs.0.64685-0.

WELLER, S. A.; STOKES, M. G.; LUKASZEWSKI, R. A. Observations on the inactivation efficacy of a MALDI-TOF MS chemical extraction method on Bacillus anthracis vegetative cells and spores. PLoS One. v. 10, e0143870, 2015. DOI: 10.1371/journal. pone. 0143870 . 